\title{
Reduced Th1 and Treg immune responses in a pediatric egg-allergic group susceptible for an OIT protocol
}

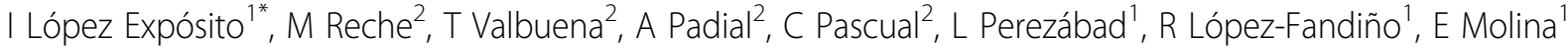 \\ From Food Allergy and Anaphylaxis Meeting (FAAM 2013) \\ Nice, France. 7-9 February 2013
}

\section{Background}

Egg allergy is one of the most common food allergies of childhood with an estimated prevalence of $2.6 \%$. Allergic reactions to egg may vary from atopic dermatitis to systemic anaphylaxis. Although traditionally the only treatment is dietary avoidance, oral immunotherapy (OIT) appears as a promising approach to induce eggtolerance. However, the immune mechanisms underlying this treatment are largely unknown. The purpose of this study was to compare the clinical and immune responses against egg allergens of a pediatric population candidate for an OIT protocol with a non-atopic population of the same age range.

\section{Methods}

A group of 19 pediatric patients with egg allergy confirmed by egg-specific IgE levels and positive double blind placebo controlled tests (DBPCT) was compared with a group of 9 non-atopic children on an egg-containing diet. The mean age of the egg-allergic patients was 10.1 years compared with 6.2 years in the control group. No significant differences regarding sex or age were found between the two groups. In both groups, PBMCs were isolated from peripheral blood and stimulated during 7 days with $200 \mu \mathrm{g} / \mathrm{mL}$ of ovalbumin (OVA). Culture supernatants were analyzed for IL-5, IL13 , IL-1 $\beta$, IFN- $\gamma$, TNF- $\alpha$ and IL-10 production by Cytometric Bead Array (CBA).

\section{Results}

During the DBPCT with pasteurized egg-white, 8 eggallergic patients had urticaria, 5 anaphylaxis, 4 experienced digestive symptoms and 2 respiratory symptoms. The mean positive dose in the DBPCT was $1.4 \mathrm{~mL}$ of egg-white, within a range of 0.001-8 mL. Specific IgE measurements revealed, on average, $71.0 \mathrm{kU} / \mathrm{L}$ for eggwhite, $31.7 \mathrm{kU} / \mathrm{L}$ for OVA and $45.6 \mathrm{kU} / \mathrm{L}$ for ovomucoid.

CBA results showed a significantly impaired production of OVA-specific IFN- $\gamma(\mathrm{P}<0.05)$, TNF- $\alpha(\mathrm{P}<0.01)$ and IL-10 $(\mathrm{P}<0.01)$ in egg-allergic patients when compared with control children. In addition, a trend toward higher OVA-specific IL-5 and IL-13 production was found in egg-allergic patients.

\section{Conclusion}

Under the conditions studied, egg-allergic children showed a significantly reduced Th1 and Treg cytokine production upon stimulation with OVA in comparison with non-atopic controls. Furthermore, a trend toward the production of IL-5 and IL-13 was observed. The clinical response to egg in the allergic group was reflected in the T-cell responses to OVA and the evolution of the cytokine profile upon a OIT protocol might provide a better understanding of the immune responses involved in allergy and tolerance to egg.

\section{Disclosure of interest}

None declared. 


\section{Author details}

${ }^{1}$ Bioactivity and Food Analysis, Institute for Food Science Research (CIAL)

(CSIC-UAM), Madrid, Spain. ${ }^{2}$ Allergy Service, Infanta Sofia Hospital, Madrid, Spain.

Published: 25 July 2013

doi:10.1186/2045-7022-3-S3-P49

Cite this article as: López Expósito et al:: Reduced Th1 and Treg immune responses in a pediatric egg-allergic group susceptible for an OIT protocol. Clinical and Translational Allergy 2013 3(Suppl 3):P49.

Submit your next manuscript to BioMed Central and take full advantage of:

- Convenient online submission

- Thorough peer review

- No space constraints or color figure charges

- Immediate publication on acceptance

- Inclusion in PubMed, CAS, Scopus and Google Scholar

- Research which is freely available for redistribution

Submit your manuscript at www.biomedcentral.com/submit
C Biomed Central 